\title{
Recasting Mr. Sage: The Renewed Interest in R.B. Bennett
}

\author{
Sean Graham, University of Ottawa
}

John Boyko, Bennett: The Rebel who Challenged and Changed a Nation (Toronto: Key Porter, 2010)

Christopher McCreery and Arthur Milnes eds. The Authentic Voice of Canada: R.B Bennett's Speeches in the House of Lords, 1941-1947

(Kingston: Queen's, 2009)

\section{P.B Waite, In Search of R.B. Bennett (Montreal: McGill-Queen's University Press, 2012)}

Recently there has been passionate debate in the op-ed pages of Canada's newspapers and history blogs over the Conservative government's commitment to historical commemoration. Some argue that the government is only celebrating events that fit within a specified political narrative centred on a narrow definition of nationalism. For others, the focus on commemoration is a welcome development that will allow Canadians to discover their past. For too long, they argue, Canada has suffered from a collective amnesia about its history. For the likes of Jack Granatstein and Andrew Cohen, one of the side effects of this has been a general failure to honour former Prime Ministers and the critical roles these figures played in shaping the country. While other countries build statues, museums, and libraries dedicated to national leaders, Canadian Prime Ministers tend to fade into history without much attention.

Traditionally cited as the biggest victim of this collective amnesia, Richard Bedford Bennett has, in recent years, started to escape the anonymity of the past in becoming the subject of plenty of discussion and study. Perhaps the most public element of this renewed interest has been the movement to have a Bennett statue commissioned for Parliament Hill, an idea which has been championed by New Brunswick teenager Jordan Grondin. Grondin, who has been quite successful in garnering media attention for his endeavour, being interviewed by the CBC, Sun News Network, and multiple print outlets, told the Toronto Star in May 2012 that he is motivated by the strong belief that Bennett deserves recognition for his work as his "most enduring parliamentary legacy is an insult" to his record. ${ }^{1}$ Grondin has been able to count some prominent Canadians as supporters of the idea, including former Prime Minister John Turner, who in a 2010 piece for The Globe and Mail explained that Bennett's absence from the Hill has always bothered him, leading him to call on politicians 
from all parties "to work together to make a Bennett statue a reality as soon as possible."2

On the other side of the argument, however, people have claimed that it would be wrong to include Bennett with the likes of Sir John A. Macdonald, Wilfred Laurier, and William Lyon Mackenzie King on Parliament Hill. Opponents of the idea argue that it would be wrong to honour a Prime Minister who is generally remembered as an unsympathetic figure who was unable to bring Canada out of the Great Depression. This perception is largely the result of Bennett's status as a reclusive, almost mysterious, man. Since his loss in the 1935 federal election, Bennett has been remembered as an austere Prime Minister with little regard for the average Canadian in the midst of the Depression. Cast as a detached aristocrat, Bennett's accomplishments tend to be forgotten by modern Canadians as he ranked twelfth in a 2011 Maclean's survey of the country's best Prime Ministers, only ranking higher than Alexander Mackenzie among Prime Ministers who served more than three years. When this is compared to the arguments supporting his inclusion on the Hill, it becomes clear that there are two diverging perceptions of Bennett and his legacy.

Born in Hopewell Cape, New Brunswick, in 1870, R.B. Bennett grew up in a modest home. His father, a second generation ship builder, suffered from a declining demand for wood ships in the 1870s and the world depression further exacerbated the family's financial situation. If his father was, as P.B. Waite describes, gregarious, reckless, and feckless, his mother served as the backbone of the family. A teacher by trade, she instilled in her eldest son a sense of personal discipline and a commitment to hard work. Perhaps motivated by her husband's poor financial management, she taught her children to account for every penny, a trait which served Bennett during his public life. Bennett had a strong affection for his mother - he returned to Hopewell every Christmas until her death - but the exact nature of their relationship remains a mystery. Following her death in 1914, Bennett destroyed all his correspondence with his mother. An intensely private person, Bennett ensured that his relationship with his mother remained between the two of them - the clues he left were statements about how his mother had been such a positive presence in his life.

When he was 16, Bennett, thanks to a small legacy his mother received, enrolled in the Provincial Normal School at Fredericton. By 1890 he was principal of a four-room school at Douglastown and was working for Lamuel Tweedie's law office in Chatham on Saturdays. With the extra money, Bennett enrolled in Dalhousie University Law School where he quickly became engaged in campus politics. He was elected premier of the student parliament in 1892, a position which he used to unite the three Maritime Provinces and Newfoundland. He was ultimately derailed, however, when he tried to give women the vote. Following school, Bennett returned to work for Tweedie, but in 1897 he moved to Calgary where he became a junior partner at the practice of 
Senator James Lougheed. It was here where he earned his reputation as a tenacious lawyer who was noted for his strong devotion to his clients. Lauded for his integrity, he meticulously ensured that there was no possible conflict of interest in any of his cases.

Bennett was again called to politics in 1898 when he was elected to represent Calgary in the North-West Territories Assembly. Two years later he unsuccessfully ran as a Conservative in the Provisional District of the Northwest Territories in the federal election. Following Alberta's entry to Confederation, however, Bennett won the seat for Calgary in the 1911 federal election, a seat he would lose in 1921. Following his re-election in 1925 - he would hold the seat for Calgary-West until his resignation in 1938 - Bennett was identified as an up and comer in the Conservative Party. In the short-lived Arthur Meighen government, Bennett was appointed Superintendent-General of Indian Affairs, Minister of the Interior, Minister of Mines, and Minister of Finance and Receiver General. Following Meighen's resignation as party leader in 1926, Bennett was looked upon as a strong candidate to take over the leadership of the Conservative Party.

Elected to that post in 1927, Bennett went on to defeat William Lyon Mackenzie King's Liberals in the 1930 federal election. Often described as a pyrrhic victory, Bennett's reward was attempting to guide Canada through the Great Depression. His government's five years are not generally remembered fondly and are marked by the Bennett buggy, the Regina Riot, and a highly publicized falling out with H.H. Stevens. He did have some successes, however, as the Bank of Canada, the Canadian Wheat Board, and the Canadian Radio Broadcasting Commission, Canada's first public broadcaster, were all founded by his government. These were not enough to earn re-election, however, as the 1935 campaign returned Mackenzie King and the Liberals to power. Bennett retained his post as Conservative leader and served as the Leader of the Opposition until 1938, when he retired and moved to Great Britain. Appointed to the British House of Lords in 1941, Bennett remained in England until his death in 1947 and remains the only Prime Minister to be buried outside of Canada.

A mercurial figure, the historiography on Bennett is rather limited. This is partly because he has never been viewed as a great Prime Minister, but his private nature - he kept very little of his private correspondence - means that there is not a substantive textual record to study. As such, it was not until recently that traditional biographies were written about Bennett. There had been biographical sketches and studies of specific moments in his life, but nobody had committed to writing a comprehensive biography of the man who led Canada through the first half of the 1930s. In the preface to the second edition of his 1934 study of Bennett, Andrew MacLean wrote that while he was not attempting to produce of biography, "the people of Canada should know something about their Prime 
Minister. The taxpayers are entitled to learn what manner of man is in charge of their affairs."3 Similarly, Ernest Watkins introduced his 1963 R.B. Bennett: A Biography by cautioning that the book was "a sketch of a man, not his biography." 4 Works like James Gray's 1991 R.B Bennett: The Calgary Years, Waite's 1992 The Loner: Three Sketches of the Personal Life and Ideas of R.B. Bennett, 18701947,5 and Larry Glassford's Reaction and Reform: The Politics of the Conservative Party Under R.B. Bennett, 1927-1938 have examined specific aspects of his life, but not to the extent of providing a complete picture of the man. Given the relative dearth of material, Bennett has remained a misunderstood figure.

P.B. Waite attempts to clarify the misunderstandings that surround the former Prime Minister with his biography In Search of R.B. Bennett. The book's title is apropos in outlining the author's view - that R.B. Bennett has been lost to history and while there may be a record of Bennett the legislator, there is no record of Bennett the man. Bennett has frequently been cast as a detached Prime Minister whose financial wherewithal prevented him from truly understanding the pain and suffering Canadians felt during the 1930s. Waite notes that this perception is more in line with the caricature of Bennett put forth by opposition newspapers - perhaps best exemplified by the Mr. Sage controversy during the 1935 federal election ${ }^{6}$ - than with the man himself. By taking the reader from Bennett's humble beginnings in 1870s New Brunswick to his 1947 death while taking a bath at his estate in England, Waite tells the story of a driven yet sensitive man whose passion and devotion to his country knew no bounds. By going beyond Bennett's five years in power, Waite offers readers the complete portrait of a man who led the country through a tumultuous period.

In a lot of ways In Search of R.B Bennett represents the best in biography. Too often biographical subjects are presented as one-dimensional figures either compassionate or callous with nothing in between. But Waite presents a nuanced picture of Bennett, a man who could equally elicit condemnation or admiration. In describing his ascent from a 16-year-old teacher to Viscount Bennett, Waite provides the ideal framework to understand Bennett's public life. By showing his passion and devotion to his Methodist roots, his beloved sister Mildred, and his one (that we know about) love interest Hazel Colville, Waite shows how Bennett's primary motivation in entering politics, and later taking leadership of the Conservative Party, was his strong sense of duty to Canada. In this way, the reader is confronted by a Bennett whose legendary temper was not precipitated by anger or hatred, but rather by a zealous desire to help his country. While there was a certain level of vanity in the Prime Minister - after all he was upset at the meagre send-off he received in Ottawa when he moved to England - Bennett was motivated in his political life by a singular need to help the country and its citizens. Whether through sound fiscal control, expanded social programs, or investing in culture, Bennett strove to respond to Canadians and their 
priorities in the $1930 \mathrm{~s}$.

In Search of R.B. Bennett comes at an interesting time, as the literature on the former Prime Minister is expanding at an unprecedented pace. It represents the third book since 2009 on Bennett, two of which have been biographies. The first of these works came in 2009, with The Authentic Voice of Canada: R.B. Bennett's Speeches in the House of Lords 1941-1947. In pointing out that Bennett is the "most neglected of Canada's full-term Prime Ministers," editors Christopher McCreery and Arthur Milnes argue that his speeches in the House of Lords are illuminating because, without the pressures of being Prime Minister, it was the first opportunity in his political life to truly do as he wished without being concerned about potential political ramifications. ${ }^{7}$ The book is broken into three sections: Bennett's speeches in the House of Lords, tributes and obituaries following his death, and his inaugural address as Rector of Queen's University as well as some articles related to the renewed interest in his life. The book does provide a much-needed source for Bennett's post-Prime Ministerial years, a period of his life that, even within the meagre historiography, has been neglected. Overall, however, the work is limited in its capacity as an edited collection of speeches.

In that respect, it served as a perfect appetizer to the entrée of the biographical works that followed; the first being John Boyko's Bennett: The Rebel Who Challenged and Changed a Nation. Similar to Waite, Boyko casts Bennett as a misunderstood figure, noting that most Canadians emerge from school with a skewed idea of his achievements despite "knowing exactly what a Bennett buggy was." It is clear that Boyko strongly believes that Bennett has been mistreated not only by historians but also the Canadian public and is writing to set the record straight on a Canadian who had a "bold vision," "fierce passion," and "led a remarkable life and career." He argues that the unfavourable consensus that has been reached about Bennett "leans upon a false stereotype, a misreading of the depth and consistency of his political principles, and refusal to acknowledge that he should be celebrated as an outstanding Canadian for his lifetime of daring and enduring accomplishments."10

Boyko also identifies a key problem when studying Bennett: his policies cannot easily be labelled as 'left' or 'right' - although he has most commonly been cast as a Red Tory. A life-long Conservative, he became increasingly interventionist during his years as Prime Minister. From the perspective of the left, this has been interpreted as a deathbed conversion in an effort to salvage his political career. On the right, however, Bennett is seen as having abandoned his core principles while governing. This difficulty in summarizing his career can help account for the unfavourable legacy as Bennett is a hero to neither side of aisle. What both Boyko and Waite rightly identify, however, is that this complexity is what makes Bennett such a remarkable figure. Despite his long political 
career, Bennett was not a politician. He did not adhere to a strict ideological framework. Given that he was generally unconcerned with political consequences, Bennett assessed each situation and took the action that he believed was best for the country. Rather than a left or right philosophy, Bennett adhered to the doctrine of self-discipline, hard work, and ambition that he inherited from his mother.

In tracing his life, Waite and Boyko employ similar methodologies as they primarily rely on archival textual records. Given the sparse historiography on Bennett, they reference material that had previously not been considered in the historical accounts of his life and career. Additionally, there is not a sense that either is writing from a nationalist perspective, but rather they approach Bennett as a misunderstood man who played a central role in the Great Depression. The principal difference between Boyko and Waite, however, is the perception each of them is trying to change. Waite's focus is primarily on the man himself. The archival collections he references show a desire to understand Bennett's personal life and relationships - the most notable of these being the Hazel Colville papers. In doing so, Bennett's legislative record is set against his generally compassionate personality. Conversely, Boyko's interest lay principally in Bennett's public life and examining his legislative legacy. He casts the Prime Minister as a rebel who drew the ire of both those on the left and right and whose astute business dealings came from his shrewd ability to see opportunity where others could not. ${ }^{11}$ Despite the different approaches, both authors point out that they are trying to revise Bennett's unwarranted reputation as a failed Prime Minister. For as much as these new studies have sought to fill a significant void in Canada's historiography, they have also been written with the clear intent of changing the public's perception of Bennett.

But one wonders why the sudden clamour to salvage the reputation of a Prime Minister seventy-five years after his death? In his introduction, Boyko suggests that the onset of the recession in the fall of 2008 thrust Bennett back into popular view. With politicians, pundits, and journalists making comparisons to the 1930s and the Great Depression, Bennett and his government's actions garnered greater public attention and scrutiny as it was hoped that they could help inform modern politics. While the economic struggles of the past few years have definitely led to a greater focus on Bennett, they do not solely account for the renewed interest in him as a historical figure. There is another factor that has led to people revisiting Bennett's life: Stephen Harper. Harper's tenure as Prime Minister has a remarkable resemblance to Bennett's: both are transplanted Albertans representing Calgary, exercise a significant degree of control over their caucuses, and are perceived as somewhat detached, out of touch leaders. While neither Boyko nor Waite directly compares the two, the resurgent interest in Bennett is, along with the economic realities of the past five years, likely the result of the parallels between his career and the current Prime Minister. 
The great irony, however, is that despite the comparisons, Bennett does not fit within the nationalist, conservative narrative that so many have accused the government of establishing in its historical celebrations - his interventionist policies during the Great Depression and emigration to England weaken his credentials. But he also does not qualify as a leftist figure either. This confusion is what makes Boyko and Waite's works such a welcome addition to the historiography. While neither work is revolutionary in its methodology, by providing a nuanced examination of Bennett they show the value of thorough historical investigation. They also prove that history cannot be confined to basic narratives. The past cannot be cherry picked - events, people, and movements have to be studied in their entirety in order to truly appreciate their historical significance. The one thing that remained constant through Bennett's career was his commitment to do what he thought was best for Canada. Ideologies, political consequences, or business considerations never mattered as much as doing what was best for the country. That mindset tends not to fit within a historical vision based on narrow political ideology. Perhaps he deserves a Parliament Hill statue after all.

\section{NOTES}

1 "Canadian Prime Minister R.B. Bennett Should Have Parliament Hill Statue, Says Teen,” Toronto Star, 31 May 2012.

2 John Turner, "Give R.B. Bennett his place on the Hill,' The Globe and Mail, 19 July 2010.

3 Andrew D. MacLean, R.B. Bennett: Prime Minister of Canada (Toronto: Excelsior Publishing Company, 1934), 7.

${ }^{4}$ Ernest Watkins, R.B. Bennett: A Biography (London: Secker \& Warburg, 1963), 11.

5 This book came out of the Joanne Goodman Lectures, which Waite delivered in 1991. The three sketches were entitled 'Hopewell Cape and the Miramichi, 1870-1897,' Work, Riches, and Empire: Calgary, 1897-1927,' and 'Mildred Bennett, Hazel Colville, and the Wages of Power and Exile, 1927-1947.' 6 The controversy was the result of a series of programs aired on the CRBC national network which featured an elderly man named Mr. Sage champion Conservative policies to skeptical friends and neighbours. The programs were paid for by the Conservative Party but were not identified as such, thus leading to accusations that the CRBC was simply an outlet for government propaganda. ${ }^{7}$ Christopher McCreery and Arthur Milnes eds. The Authentic Voice of Canada: R.B. Bennett's Speeches in the House of Lords, 1941-1947 (Kingston: Queen's, 2009), $\mathrm{xv}$. 
116 Graham

8 John Boyko, Bennett: The Rebel Who Challenged and Changed a Nation (Toronto: Key Porter, 2010), 25.

9 Boyko, 26.

10 Boyko, 23.

11 Boyko does make a notable factual error, however, when he states that the assertion that Mackenzie King created the $\mathrm{CBC}$ is a falsehood. The $\mathrm{CBC}$ was created in 1936 by the Mackenzie King government while the Bennett government passed legislation establishing the Canadian Radio Broadcasting Commission in 1932. A common interpretation is that the CBC was simply a rebranding CRBC, but the distinctions between the two organizations were much more substantial and, as a result, they need to be viewed as separate entities. 